\section{Beyond Alchemy}

A History of Chemistry. Vol. I, Part 1: Theoretical Background. By the late J. R. Partington. Pp. xiv +370 . (Macmillan: London; St Martin's: New York, December 1970.) $£ 10$.

We all know that Partington did not finish preparing his great work for the press and that the material which should have made up Part 2 of Volume I still presents editorial problems of great complexity. So we are in the curious position of having Vol. I, Part 1, and three other volumes (II, III and IV). The latter begin where it was often convenient to begin the history of chemistry, that is to say with the technological treatises of the 16 th century in the ascendant and with alchemy in disreputable decline. If we had only these three we should still be rich. For all its exasperating inconsistency and its disorderly array of irrelevance it is a marvellous quarry of material. A quarry, however, not an edifice. $D e$ mortuis: but one must be critical. Partington was apt to censure others for being unhistorical when they filled gaps in knowledge with imaginative inference. But he was open to the charge of refusing to indicate how inference might be guided. Superficially he did the historian's first duty, the duty to narrate, but he never really learned to tell an extended story. His Presidential Address of 1951 to the British Society for the History of Science, "Chemistry as Rationalized Alchemy", which is printed as a preface to Vol. I, Part 1, is, indeed, an attempt to condense the history of chemistry in a single pièce doccasion, but is little more than a succession of comments on individuals.

The merit of the History of Chemistry lies not in its form, which is a glorious muddle, but in its bulk. Clearly, it was put together by the accumulation of notes made over many years, with each paragraph edited to give it some balance, but often with little connective matter to help guide the reader. Ask what Plato or Aristotle thought about water and you get long answers. Ask how the idea of the nature of water changed and one has to make up an answer out of dozens of bits and pieces. But this is to criticize Partington for what he asserted he was doing. If we look at what he really did it looks different.

This is, in fact, no history but a kind of encyclopaedia arranged by authors, in rough chronological order, so detailed in its summation of the work of each as to have also something of the character of an anthology. Recognizing this can give us some relief and encouragement. A real history of chemistry would be so enormous as to leave little room for anything to grow in its shade. It is instructive, however, to read parallel passages of Sarton's History of Science (the late work, not the Introduction). Lucretius, for example, is dismissed as a person by Partington in a dozen lines, as an accurate source for the doctrine of Epicurus, which is then dealt with at length. Sarton elicits from the character of the poem not only a portrait of the poet but also an evocation of the significance of Epicurean atomism for our understanding of the scientific thought of the time. Sarton is deficient in fact, Partington deficient in insight. Obviously there is room here for a substantial twentieth century appreciation of Lucretian Epicureanism, but, more to the point for the ordinary student, no one need feel that he must be overawed by the existence of earlier work from having a go on his own at big topics.

Looked at in this way the value of a great part of this volume is clear. Anyone wanting to tackle any aspect of the history of chemistry from the early Greeks onwards will find here usually a summary, and sometimes a complete list, of the main ideas and assertions of every relevant author.

But if the history of chemistry is a history of ideas about the nature and meaning of matter, do we not need to see the development of ideas in terms of the common and individual experiences which the philosophers thought it necessary to interpret? Partington examines nothing and relates nothing. One begins to suspect that he had no faculty for deciding on the relative value of material. If he had, would he not have given some introduction to the last chapters on the mystery religions? We need some modern study of their relation to both alchemical and nonalchemical ideas in chemistry. It is difficult to see from Partington how Manichaeism, Grosticism or Mithraism contributed to the philosophy of matter, let alone chemistry, from these long lists of purely religious or bibliographical observations, often culled, as in the case of the Sabians, from rather few secondary sources.

We are left with no real beginning to our history of chemistry. Anyone who wants real origins had better turn to Multhauf. But for all its shortcomings, the still incomplete Partington is bigger and fuller than anything else we have or are likely to have for some generations. So we shall reluctantly pay the high price for this latest part because we cannot do without it.

Frank Greenaway

\section{Medicine Morals}

Science and Morality in Medicine: a Survey of Medical Educators. By EarI R. Babbie. Pp. xviii +261 . (University of California: Berkeley, Los Angeles, and London, 1970.) \$7.50.

There was a time when the chief function of the physician was to prevent his patient from behaving foolishly and to give him moral support in case of illness. Little was understood of the process of disease and little could be done to alter their course and outcome. The growth of scientific knowledge and the development of a technology based on science has altered all that. Medicine has succeeded in altering the whole structure of society and its outlook. The Indian sub-continent is rapidly progressing to a state of such over population that the mind boggles at the probable outcome. The wealthier societies become top heavy with aged pensioners.

Medical care is seen by many as an elementary human right. Irrespective of race, colour or creed, all should have access to it. Unfortunately the facts do not admit of this. When the practice of medicine has become so refined an art as it is today, the difference between the best and the worst, between the most able and the best trained and the less able and the worst trained, is enormous. Medicine has in the past been a profession in which distinction has carried the privileges of fame, position and wealth. The best achieve this simply by excellence, but there have always been others who achieved wealth by less admirable means. These are some of the factors lying behind the present situation in the United States. The American Medical Association has fought against what it calls socialized medicine and for free enterprise in medicine. Its success has gained great wealth for the profession but it has not been quite so happy for the patient.

When things go wrong, or seem to go wrong, it is customary to find a scapegoat. Science is the first choice of the contemporary world. It is said that the decline of morality in medicine is due to corrosion by science and scientists. To find out by sociological methods, or methodology, as the author would put it (long words are scientific), is the purpose of this book. A questionnaire (15 pages in length) of 67 questions was sent to 627 full-time faculty members in medicine and paediatrics at 12 of the nation's medical colleges. 454 (72\%) completed the questionnaire. How different was the response of part-time faculty members; only $17 \%$ completed theirs. No doubt they were busy attend- 